\author{
MARZENA CZERNICKA
}

Instytut Studiów Politycznych PAN

ORCID: 0000-0002-2317-2169

\title{
Wspólczesna Bułgaria w obliczu wybranych zagrożeń politycznych, ekonomicznych i społecznych
}

\author{
Security problems of modern Bulgaria
}

Contemporary Bulgaria has been a member state of NATO since 2004 and a member state of the European Union (EU) since 2007. Thanks to the accession to these organisations, Bulgaria has been included in the European-Atlantic structures, and the level of security of this country has increased significantly. Nevertheless, threats and problematic issues concerning the security of contemporary Bulgaria continue to exist, and these threats mostly come from inside the country. There are different kinds of political, economic and social problems. This article describes the above-mentioned problems by concentrating on the threats that, according to the author, are the most difficult to solve and seem to be most significant regarding the context of Bulgaria's security.

Keywords: Bulgaria, security, threats, Russia, European Union

Słowa kluczowe: Bułgaria, bezpieczeństwo, zagrożenia, Rosja, Unia Europejska

Współczesna Bułgaria jest państwem niezależnym i niepodległym. Stało się to możliwe na początku lat dziewięćdziesiątych XX w., kiedy upadł Związek Radziecki ${ }^{1}$ i rozpoczęła się demokratyzacja kraju². Ówczesna sytuacja międzynarodowa oraz rozpoczęcie reform wewnętrznych stworzyły Bułgarii szansę na stanie się pełnoprawnym uczestnikiem stosunków międzynarodowych,

1 Szerzej nt. upadku ZSRR zob. J. Holzer, Komunizm w Europie. Dzieje ruchu i systemu władzy, Dom Wydawniczy „Bellona”, Warszawa 2000; J. Wojnicki, Trudna droga do demokracji. Europa Środkowo-Wschodnia po 1989 roku, Wydawnictwo Autorskie, Warszawa 2002.

2 E. Bujwid-Kurek, D. Mikucka-Wójtowicz, Transformacja ustroju politycznego wybranych państw Europy Środkowej i Poludniowo-Wschodniej, Wydawnictwo „Libron”, Kraków 2015; Bulgaria in transition. Politics, economics, society and culture after communism, ed. J.D. Bell, Westview Press, Colorado 1998. 
czego wyrazem jest np. integracja euroatlantycka. Dzięki członkostwu w UE i NATO znacznie polepszyła się sytuacja wewnętrzna państwa i wzrosła jego pozycja na arenie międzynarodowej. Nadal jednak, pomimo wielu korzyści płynących z przynależności do tych struktur, Bułgaria musi się mierzyć z problemami i zagrożeniami dla bezpieczeństwa państwa, w przeważającej części wynikającymi z czynników wewnętrznych.

Prowadzona od kilku lat obserwacja życia społeczno-politycznego Bułgarii ${ }^{3}$ pozwala wysunąć tezę, że państwo to stoi w obliczu wielu zagrożeń, z których najtrudniejsze do ograniczenia wydają się te o charakterze politycznym, ekonomicznym i społecznym. Spośród pierwszych za najbardziej niebezpieczne uznaję brak stabilności politycznej, brak rozliczenia z przeszłością komunistyczną oraz wzrost możliwości zewnętrznej ingerencji w sprawy państwa. Wśród ekonomicznych jako najistotniejsze traktuję zagrożenia energetyczne wynikające $\mathrm{z}$ deficytu zasobów surowcowych i braku dywersyfikacji źródeł energii, z czym wiąże się prawie całkowite uzależnienie od surowców rosyjskich. Innym czynnikiem, który ma negatywny wpływ na sytuację Bułgarii, jest niski poziom rozwoju społeczno-gospodarczego. Najbardziej niebezpieczne spośród zagrożeń społecznych są moim zdaniem kłopoty demograficzne, w szczególności depopulacja i emigracja zarobkowa. Istotnym problemem są również nieetyczne zachowania elit politycznych, jak korupcja i przestępczość. Ogólnie w Bułgarii obserwuje się niski poziom zaufania obywateli do instytucji publicznych i polityków. Wszystkie te zagrożenia mają negatywny wpływ na stan państwa, hamują jego rozwój i negatywnie rzutują na wizerunek Bułgarii na arenie międzynarodowej.

Zagrożenia społeczne można ograniczać poprzez skuteczną politykę gospodarczą i społeczną, jak krajowe programy walki z korupcją. Problemy o charakterze politycznym i ekonomicznym wydają się natomiast o wiele bardziej brzemienne w skutki i dużo trudniejsze do zneutralizowania, dlatego

3 Warto zapoznać się z wydawanym w Lublinie „Rocznikiem Instytutu Europy Środkowo-Wschodniej” oraz archiwalnymi wydaniami rocznika ISP PAN „Europa Środkowo-Wschodnia”. Zob. Rocznik Instytutu Europy Środkowo-Wschodniej, „Instytut Europy Środkowo-Wschodniej” [online, dostęp: 1 IX 2019], dostępny w internecie: <http:// www.iesw.lublin.pl/rocznik/spisroczniki.php>. Istnieje też bogata literatura traktująca o Bułgarii i Bałkanach, zarówno z perspektywy historycznej, jak i z uwzględnieniem aktualnych problemów. Zob. np.: M. Dymarski, Konflikty na Bałkanach w okresie ksztattowania się państw narodowych $w$ XIX $i$ na poczatku XX wieku, Wydawnictwo Uniwersytetu Wrocławskiego, Wrocław 2010; M. Tanty, Bałkany w XX wieku. Dzieje polityczne, Wydawnictwo „Książka i Wiedza”, Warszawa 2003; R. J. Crampton, Bulgaria, Oxford University Press, Oxford 2008. 
uznaję je za najbardziej niebezpieczne. Takie zagrożenia polityczne jak częste zmiany rządów istotnie utrudniają wprowadzanie reform, a zatem nie sprzyjają demokratyzacji państwa. Rzutują tym samym na jego bezpieczeństwo polityczne i społeczne. Nieudolnie prowadzona polityka sprzyja wzrostowi niezadowolenia obywateli oraz obniżeniu poziomu zaufania do instytucji publicznych i polityków, a w rezultacie występowaniu kolejnych negatywnych zjawisk, jak protesty czy strajki. Zagrożenia ekonomiczne, np. deficyt własnych zasobów surowcowych połączony z brakiem dywersyfikacji źródeł energii, przekładają się na realny problem zależności energetycznej oraz obawy o wzrost możliwości zewnętrznej ingerencji w sprawy państwa.

Zasadniczą tezę niniejszego artykułu postawiłam w oparciu o analizę źródeł zastanych, dostępnych w językach polskim, angielskim i bułgarskim. Należą do nich m.in. monografie, artykuły naukowe i prasowe, dokumenty, dane statystyczne, sprawozdania i raporty. Do analizy problemu wykorzystuję metodę historyczną, która pozwoli na przedstawienie właściwego kontekstu funkcjonowania współczesnej Bułgarii oraz wyjaśnienie przyczyn zjawisk i procesów, które tam obserwujemy. Dostępne dane ilościowe umożliwią zaś np. omówienie kwestii demograficznych.

\section{Zagrożenia polityczne i ekonomiczne}

Od początku lat dziewięćdziesiątych XX w. Bułgaria nieprzerwanie zmaga się z niestabilną sytuacją polityczną i często dochodzi tam do przedterminowych wyborów parlamentarnych. Między 1990 a 2001 r. były to aż trzy z czterech elekcji: w 1991, 1994 i 1997 r. Pierwszą pełną kadencję po upadku komunizmu przetrwał dopiero powołany w 1997 r. rząd Iwana Kostowa ze Związku Sił Demokratycznych (ZSD). Przyczyny tak częstego rozpisywania wyborów w Bułgarii lat dziewięćdziesiątych (podobnie $\mathrm{z}$ resztą jak w innych postkomunistycznych państwach Europy Środkowo-Wschodniej) wyjaśnia Jacek Wojnicki ${ }^{4}$. W pierwszej kolejności wskazuje uchwalenie nowej konstytucji i wprowadzenie nowych instytucji politycznych, a następnie konieczność zażegnania kryzysów politycznych poprzez odwołanie się do woli wyborców. Uchwalenie nowej konstytucji w lipcu 1991 r. (notabene wcześniej niż w Polsce) faktycznie dało impuls do przyspieszenia wyborów parlamentarnych i już w październiku 1991 r. władza przeszła w ręce opozycji skupionej

4 J. Wojnicki, Alternacja władzy w państwach Europy Środkowo-Wschodniej po 1990 roku, „Studia Politicae Universitatis Silesiensis” 2011, t. 7, s. 115-133. 
w liczącej niemal dwadzieścia ugrupowań koalicji ZSD. Trzy lata ich rządów doprowadziły do następnych przedterminowych wyborów w grudniu 1994 r. W rezultacie wygranej Bułgarskiej Partii Socjalistycznej (BPS) premierem został Żan Widenow, ale i on nie potrafił zaradzić napięciom na krajowej scenie politycznej ani problemom gospodarczym państwa. Nieudolne rządy Widenowa i jego konflikt z prezydentem Żeliu Żelewem doprowadziły do kolejnych przedterminowych wyborów w kwietniu 1997 r. Tym razem jednak sformowany rząd funkcjonował już pełną czteroletnią konstytucyjną kadencję $e^{5}$. Warto w tym miejscu zaznaczyć, że przedterminowe elekcje w 1994 i 1997 r. odbywały się w warunkach kryzysów politycznych i pogarszającego się stanu gospodarki (w latach 1994-1997 odnotowano w Bułgarii najgłębszy kryzys po 1990 r.). Kolejne wybory parlamentarne, w 2001, 2005 i 2009 r., zarządzano już zgodnie z terminami określonymi w ustawie zasadniczej ${ }^{6}$. Następna przedterminowa elekcja odbyła się dopiero w $2013 \mathrm{r}$.

Początek XXI w., czyli okres przygotowań Bułgarii do członkostwa w NATO i Unii Europejskiej, można uznać za czas względnie stabilny. Polepszyła się wówczas kondycja gospodarcza państwa. Stopniowo zaczęto też wdrażać reformy wewnętrzne ${ }^{7}$, mające na celu dostosowanie się do wymogów unijnych.

W 2006 r. powstała partia Obywatele na rzecz Europejskiego Rozwoju Bułgarii (GERB), głosząca konieczność ściślejszej integracji z UE, zwalczenia korupcji i polepszenia warunków życia obywateli ${ }^{8}$. W wyborach w $2009 \mathrm{r}$. zdobyła ona duży kredyt zaufania, uzyskując niemal 40 proc. poparcia, i od tej pory jest stale obecna w bułgarskim parlamencie. Szybko jednak okazało się, że obietnice wyborcze nie będą realizowane, i z każdym kolejnym rokiem narastało $\mathrm{w}$ społeczeństwie rozczarowanie polityką rządzących.

5 Tamże. Szerzej na ten temat zob. roczniki ISP PAN „Europa Środkowo-Wschodnia”, a także E. Kalinova, I. Baeva, B"lgarskite prehodi 1939-2010, Izdatelstvo „Paradigma”, Sofiâ 2010, s. 239-323. Ciekawą pozycją na temat partii politycznych w Bułgarii jest praca E. Pioskowik, Butgaria, [w:] Partie i systemy partyjne państw Europy Środkowej $i$ Wschodniej, red. M. Migalski, Wyższa Szkoła Zarządzania i Marketingu, Sosnowiec 2005; G. Karasimeonov, Partijnata sistema v B"lgariâ, Izdatelstvo „Nik”, Sofiâ 2010.

6 Tamże. Wyniki wyborów z 2013 r. dostępne są na stronie Centralnej Komisji Wyborczej w Bułgarii: Rezultati ot izbori za narodni predstaviteli 12.05.2013 g., „Centralna izbiratelna komisiâ" [online, dostęp: 1 IX 2019], dostępne w internecie: $<$ http://results.cik.bg/ pi2013/rezultati/index.html>.

7 R. Woźnica, Butgarska polityka wewnętrzna a proces integracji z Unia Europejska, Księgarnia Akademicka, Kraków 2011.

8 Strona internetowa partii: „GERB” [online, dostęp: 8 VIII 2019], dostępna w internecie: $<$ http://www.gerb.bg/bg $>$. 
Za początek kolejnego poważnego kryzysu politycznego i społecznego w Bułgarii można uznać rok 2013. Niezadowolenie społeczne sięgnęło zenitu, gdy okazało się, że za składanymi obietnicami wyborczymi nie poszły czyny. Czarę goryczy przelało podniesienie cen za energię ${ }^{9}$, po którym w największych miastach Bułgarii nastąpiła fala ulicznych protestów ${ }^{10}$. Konsekwencją tych wydarzeń była dymisja premiera Bojka Borisowa. Warto tu zauważyć, że jak na bułgarskie standardy rządził on względnie długo, bo od 2009 do 2013 r. W ciągu kolejnych dwóch lat stanowisko szefa rządu zajmowały aż cztery różne osoby: od marca do maja 2013 r. Marin Rajkow, od maja 2013 do sierpnia 2014 r. Płamen Oreszarski, od sierpnia do listopada 2014 r. Georgi Bliznaszki, a po nim znów Bojko Borisow, kierujący sprawami państwa nieco dłużej niż poprzednicy - do stycznia 2017 r., gdy po zwycięstwie Rumena Radewa ${ }^{11}$ w wyborach prezydenckich ponownie podał się do dymisji. W marcu $2017 \mathrm{r}$. doszło więc w Bułgarii do trzecich w ciągu czterech lat przedterminowych wyborów parlamentarnych. W rezultacie zwycięstwa partii GERB ${ }^{12}$ tekę premiera po raz trzeci objął Borisow.

Nakreślony powyżej obraz jasno pokazuje, że częste zmiany rządów w Bułgarii nie sprzyjają utrzymaniu stabilności politycznej państwa. Powoduje to, że politycy nie są $\mathrm{w}$ stanie prowadzić długofalowych działań na rzecz realizacji reform, co przekłada się na frustrację społeczeństwa i brak zaufania Bułgarów do polityków i instytucji demokratycznych, czego wyrazem są np. protesty uliczne.

Istotnym zagrożeniem politycznym są też w Bułgarii nieetyczne praktyki w kręgach władzy - korupcja i nepotyzm, a raczej klientelizm. Przyczyną fali protestów społecznych w 2013 r. było nie tylko podniesienie cen za energię, ale w dużym stopniu także jawna korupcja i faworyzowanie ludzi biznesu

9 Fala protestów obalita butgarski rząd, „W Polityce” [online], 22 II 2013 [dostęp: 28 X 2018], dostępny w internecie: <https://wpolityce.pl/polityka/151584-fala-protestow-obalila-bulgarski-rzad>; Parlament przyjąt dymisję rzadu Bojko Borisowa, „Newsweek” [online], 21 II 2013 [dostęp: 28 X 2018], dostępny w internecie: <http://www.newsweek. $\mathrm{pl} /$ swiat/bulgaria--parlament-przyjal-dymisje-rzadu-bojko-borysowa,101715,1,1.html $>$.

10 V.I. Ganev, Bulgaria's year of civic anger, „Journal of Democracy” 2014, vol. 25, No. 1, s. 33-45, dostępny w internecie [dostęp: 30 X 2018]: <https://www.journalofdemocracy. org/article/legacies-1989-bulgarias-year-civic-anger $>$.

11 Radew zaprzysiężony na prezydenta, „TVN 24” [online], 19 I 2017 [dostęp: 10 X 2017], dostępny w internecie: <https://www.tvn24.pl/wiadomosci-ze-swiata,2/bulgaria-rumen-radew-prezydentem,708401.html $>$.

12 Rezultati ot parlamentarni izbori 26 mart 2017. Sumarni danni, „Centralna izbiratelna komisiâ" [online, dostęp: 10 X 2017], dostępne w internecie: <https://web.archive.org/ web/20170331173208/http://results.cik.bg/pi2017/rezultati/index.html>. 
powiązanych ze światem polityki, np. powołanie biznesmena i potentata medialnego Delana Peewskiego na szefa Państwowej Agencji Bezpieczeństwa Narodowego (DANS) ${ }^{13}$. Warto przyjrzeć się specyfice i charakterystyce tych protestów, co czynią np. Delia Hallberg i Marinus Ossewaarde ${ }^{14}$. Przywołując opinie różnych badaczy, pokazują, że wydarzenia w Bułgarii wpisują się w widoczną na świecie po 2011 r. nową falę protestów, które łączą pewne cechy wspólne: inkluzywność (udział różnych grup społecznych), duża rola mediów społecznościowych (np. Facebooka i Twittera), pokojowy charakter oraz cele protestujących i ich stosunek do otaczającej rzeczywistości. Główną przyczyną protestów w Bułgarii jest głęboka nieufność do wszystkich partii politycznych i koalicji. Protestujący domagają się nie tylko zmian w rządzie, ale i fundamentalnych reform - zlikwidowania korupcji, nepotyzmu oraz niejasnych powiązań polityki ze środowiskami biznesowymi i przestępczymi. Najbardziej jaskrawymi przykładami społecznej frustracji przeciwko całemu systemowi były odnotowane w niektórych miastach przypadki samospaleń. Oto jak na temat sytuacji wewnętrznej i stanu demokracji w swoim państwie wyrażał się uznany bułgarski politolog Iwan Krystew:

Kraj jest klasycznym przykładem wszystkiego, co jest nie tak z demokracją - korupcja, nieudolne instytucje, publiczna apatia - i podręcznikowym przykładem, dlaczego demokracja jest wciąż naszą najlepszą nadzieją, ze swoim potencjałem do zmobilizowania ludzkiej energii i umożliwienia ludziom pokojowego obalenia rządów, które muszą odejść ${ }^{15}$.

Problemem współczesnej Bułgarii jest także wciąż nierozliczona przeszłość komunistyczna. Brak odpowiednich rozwiązań ustrojowych (prawnych i instytucjonalnych) powoduje, że w przestrzeni publicznej i na scenie politycznej

13 D. Hallberg, M. Ossewaarde, Protest and recognition in the Bulgarian summer 2013 movement, [w:] Protest, social movements and global democracy since 2011. New perspectives research in social movements, conflicts and change, ed. T. Davies, H.E. Ryan, A. Milciades Pena, Emerald Group Publishing Limited, Bingley 2016, s. 85-106 (Research in Social Movements, Conflicts and Change, 39). Zob. też: D. Margarit, Ideology and social movements. A comparative analysis of the 2013 protests in Bulgaria, Hungary and Romania, [w:] Social movements in Central and Eastern Europe. A renewal of protests and democracy, ed. G. Pleyers, I.N. Sava, Universității din București, București 2015, s. 13-26; H. Ambareva, Protests, politics and values in Bulgaria 2013, [w:] Social movements..., s. 27-33.

14 D. Hallberg, M. Ossewaarde, Protest...

15 I. Krastev, Why Bulgaria's protest stand out in Europe, „The Guardian” [online], 30 VII 2013 [dostęp: 30 X 2018], dostępny w internecie: <https://www.theguardian.com/ commentisfree/2013/jul/30/bulgaria-protests-europe $>$. 
aktywnie działają osoby z bogatą przeszłością komunistyczną. Fakt współpracy z dawnymi służbami bezpieczeństwa nie wiąże się w Bułgarii z żadnymi sankcjami prawnymi ani zakazem obejmowania konkretnych stanowisk; lustracja sprowadza się jedynie do upublicznienia informacji oraz sankcji moralnych. W latach dziewięćdziesiątych pojawiały się głosy, by dokonać pełnego otwarcia archiwów państwowych, ale nigdy do tego nie doszło, głównie ze względu na brak woli politycznej, by zająć się tym problemem ${ }^{16}$. Pierwszym państwowym dokumentem mającym charakter lustracyjny była uchwalona w 1992 r. 'Ustawa tymczasowo wprowadzająca dodatkowe wymagania wobec członków kierownictwa instytucji naukowych i uczelni wyższych', zwana potocznie ustawą Georgiego Panewa ${ }^{17}$. Zakładała ona przeprowadzenie lustracji we wszystkich gremiach decyzyjnych instytucji naukowych i uczelni wyższych. Zasiadające w nich osoby musiały udowodnić, że nie zajmowały czołowych stanowisk w partii komunistycznej ani policji bezpieczeństwa, w przeciwnym razie pozbawiane były możliwości sprawowania funkcji na pięć lat ${ }^{18}$. Wykonywanie ustawowego obowiązku przerwano, gdy w 1995 r. władza przeszła w ręce BPS. Pierwszym w Bułgarii prawem stricte lustracyjnym była 'Ustawa o dostępie do dokumentów byłej policji bezpieczeństwa’ uchwalona w lipcu 1997 r. ${ }^{19}$, a cztery lata później znowelizowana. Wdrożenie ustawy powierzono Radzie Ministrów, a na jej mocy powołano specjalne komisje, które miały się zająć egzekwowaniem nowych przepisów - najpierw komisję Bogumiła Bonewa, a nastęnie komisję Metodego

16 Warto też wspomnieć, że w latach dziewięćdziesiątych część dokumentów została zniszczona.

17 Zakon za vremenno $v^{\prime \prime}$ veždane na nâkoi dop"lnitelni iziskvaniâ $k$ "m členovete na $r^{\prime \prime k o v o d s t v a t a ~ n a ~ n a u c ̌ n i t e ~ o r g a n i z a c i i ~ i ~ V i s s ̌ a t a ~ a t e s t a c i o n n a ~ k o m i s i a ̂, ~} 24$ XII 1992, dostępny w internecie [dostęp: 21 X 2019]: <https://desebg.com/images/stories/videos/Pdf/ Zakon_Panev.pdf>. Zob. też: H. Cartner, Decommunization in Bulgaria, Human Rights Watch, Helsinki 1993 (The News from Helsinki Watch, 5, 14), dostępny w internecie [dostęp: 30 X 2018]: <https://www.hrw.org/sites/default/files/reports/BULGARIA938. PDF>; Ch. Christova, D. Foerger, Lustration - addressing the consequences of the communist regime in Bulgaria, ,International Reports” 2008, issue 1, dostępny w internecie [dostęp: 30 X 2018]: <https://www.kas.de/c/document_library/get_file?uuid=c4ffe7a7-4acb-e85b-a22a-0a6be7f95930\&groupId=252038>; H. Hristov, Propusnatite istoričeski momenti za lustraciâ v B"lgariâ, „,D"ržavna sigurnost” [online], 1 II 2011 [dostęp: $22 \mathrm{X}$ 2019], dostępny w internecie: <https://desebg.com/lustracia/79-2011-02-01-00-13-56>.

18 Szerzej: M. Nowakowski, Bułgaria, [w:] Lustracja w krajach Europy Środkowej i państw bałtyckich, red. P. Bukalska i in., Ośrodek Studiów Wschodnich, Warszawa 2009.

19 Tamże. Zob. także: Zakon za dost"p do dokumentite na bivšata D"ržavna sigurnost, 6 VIII 1997, dostępny w internecie [dostęp: 22 X 2019]: <https://desebg.com/images/ stories/videos/Pdf/Zakon-Za-dosietata-1997.pdf>. 
Andrejewa ${ }^{20}$. Ich działania doprowadziły do ujawnienia kilkudziesięciu nazwisk polityków współpracujących z dawną partią komunistyczną, ale w 2002 r. prace te zostały zablokowane mocą 'Ustawy o ochronie tajemnicy państwowej’ ${ }^{21}$, która ograniczyła dostęp do informacji i doprowadziła do całkowitego zamknięcia archiwów. Należy tu jednak zaznaczyć, że ustawa z 1997 r. nie była doskonała: poza ujawnieniem faktu współpracy nie przewidywała żadnych konkretnych sankcji wobec zweryfikowanych osób, a ponadto już na początku jej obowiązywania z obowiązku lustracyjnego wyłączono prezydenta, kandydatów na ten urząd oraz członków Sądu Konstytucyjnego ${ }^{22}$. Zamknięcie archiwów w 2002 r. całkowicie zablokowało możliwość weryfikacji życiorysów polityków i innych uczestników życia publicznego, pozostawiając tę sferę niezbadaną należycie pod kątem współpracy ze służbami bezpieczeństwa reżimu komunistycznego. Obecnie kwestie lustracyjne reguluje przyjęta w 2006 r. 'Ustawa o dostępie i odtajnieniu dokumentów oraz ujawnieniu współpracy obywateli bułgarskich ze Służbą Bezpieczeństwa i służbą wywiadowczą Bułgarskiej Armii Ludowej'23. $\mathrm{Na}$ jej podstawie powołano dziewięcioosobową komisję, która odnosi pewne sukcesy. Wspomniany już wyżej brak woli politycznej, ale przede wszystkim fakt, że ujawnienie współpracy nie wiąże się z żadnymi innymi konsekwencjami poza sankcjami moralnymi, powodują jednak, że próby lustracji kończą się w Bułgarii niepowodzeniem.

W kontekście rozliczania się Bułgarii z własną przeszłością warto poświęcić kilka słów stosunkowi Bułgarów do poprzedniego systemu. Z opublikowanego przez bułgarski ośrodek badawczy Alpha Research raportu z okazji dwudziestopięciolecia upadku komunizmu wynika, że wielu obywateli nie ma podstawowej wiedzy na temat tego rozdziału w historii państwa, a nostalgia za dawnym systemem wciąż jest obecna w społeczeństwie. Prawie połowa Bułgarów uważa lata komunizmu za korzystne dla rozwoju kraju, a dokładnie co drugi negatywnie

20 H. Hristov, Komisiâta ,,Bonev” $i$ neefektivnostta na p"rviâ zakon za dosietata, „D”ržavna sigurnost" [online], 13 X 2011 [dostęp: 22 X 2019], dostępny w internecie: <https:// desebg.com/komisii/436-2011-10-13-19-24-10>. Szerzej temat tych i kolejnych komisji zob.: Komisiâ, „Regist"r na s"trudnicite na d"ržavna sigurnost i razuznavatelnite službi na BNA" [online, dostęp: 23 X 2019], dostępny w internecie: <https://agentibg.com/ index.php/bg/2014-02-19-06-31-22/2014-02-19-06-33-02>.

21 Tamże; Zakon za zaŝita na klasificiranata informaciâ, 30 IV 2002, „B"lgarskiât praven portal" [online, dostęp: 22 X 2019], dostępny w internecie: <https://www.lex.bg/laws/ ldoc/2135448577>.

22 M. Nowakowski, Butgaria...

23 Zakon za dost"p i razkrivane na dokumentite i za obâvâvane na prinadležnost na b"lgarski graždani $k^{\prime \prime} m$ d"ržavna sigurnost $i$ razuznavatelnite službi na B"lgarskata narodna armiâ, „B"lgarskiât praven portal” [online, dostęp: 30 X 2018], dostępny w internecie: $<$ https://www.lex.bg/laws/ldoc/2135540283>; Komisiâ... 
ocenia transformację. Autorzy raportu alarmują, że 94 proc. młodzieży nie wie nic o czasach sprzed 1989 r., a między 1991 a 2014 r. sympatie względem komunistycznego polityka Todora Żiwkowa wzrosły z 16 do 55 proc. ${ }^{24}$

Kolejnym politycznym zagrożeniem dla bezpieczeństwa Bułgarii jest wzrost prawdopodobieństwa zewnętrznej ingerencji w sprawy państwa, jak można przypuszczać - głównie rosyjskiej. Dotyczy to w szczególności kwestii energetycznych, ponieważ Rosja jest dla Bułgarii jedynym dostawcą ropy naftowej i gazu ziemnego. Bardzo prawdopodobne jest też jednak ingerowanie przez Moskwę w bułgarską scenę polityczną. Przyczyny takiego stanu rzeczy to: bliskość geograficzna obu krajów, deficyt zasobów surowcowych w Bułgarii, brak infrastruktury pozwalającej na dywersyfikację dostaw surowców energetycznych oraz wspólna historia i związany z nią sentyment Bułgarów do Rosji.

Państwo rosyjskie od zawsze zainteresowane było posiadaniem wpływów na Półwyspie Bałkańskim ${ }^{25}$. Jest to obszar strategiczny dla stosunków międzynarodowych: znajduje się blisko Azji, Europy i Rosji, na skrzyżowaniu międzynarodowych szlaków komunikacyjnych i handlowych między Europą a Bliskim i Środkowym Wschodem. Bałkany od wieków były obiektem rosyjskiej polityki zagranicznej, szczególnie w XVII, XVIII i XIX w. Ważnym czynnikiem umożliwiającym osiąganie sukcesów w regionie była religia. Głosząca ideę panslawizmu ${ }^{26}$ Rosja stawiała się $\mathrm{w}$ roli obrońcy prawosławia, które dla bałkańskich Słowian, a więc także Bułgarów, było fundamentem przejawianych w XIX w. aspiracji niepodległościowych. Rosja wydatnie przyczyniła się do wyparcia z Bałkanów Imperium Osmańskiego i odzyskania niepodległości przez Bułgarię w 1878 r., dlatego też Bułgarzy darzą sympatią ówczesnego cara Aleksandra II Romanowa. Zarówno czynnik religijny, jak i wspólna kultura słowiańska ułatwiały później polityczne i gospodarcze podporządkowanie sobie tego państwa przez Związek Radziecki i włączenie go do międzynarodowych struktur komunistycznych - Rady Wzajemnej

24 Prehod"t: mitove i pamet. 25 godini po-k"sno, Alpha Research, 9 XI 2014, dostępny w internecie [dostęp: 30 X 2018]: <https://alpharesearch.bg/userfiles/file/Prehod_press release_091114.pdf $>$.

25 Istnieje szeroka literatura przedmiotu na ten temat. Zob. np.: M. Tanty, Konflikty batkańskie w latach 1878-1918, Państwowe Zakłady Wydawnictw Szkolnych, Warszawa 1968; T. Wasilewski, Historia Bułgarii, Zakład Narodowy im. Ossolińskich, Wrocław 1988; R. Kłaczyński, Polityka Imperium Rosyjskiego wobec państw, narodów batkańskich 1826-1914, „Studia Środkowoeuropejskie i Bałkanistyczne” 2017, t. 26, s. 69-81; J. Sobczak, Kwestia bałkańska $w$ rosyjskiej polityce zagranicznej z przełomu XIX i XX wieku i jej polskie epizody, „Acta Polono-Ruthenica” 2003, nr 8, s. 161-180.

26 Szerzej na temat idei panslawizmu: P. Eberhardt, Rosyjski panslawizm jako idea geopolityczna, „Geopolityka” [online], 19 V 2012 [dostęp: 1 XI 2018], dostępny w internecie: $<$ http://geopolityka.net/rosyjski-panslawizm-jako-idea-geopolityczna/>. 
Pomocy Gospodarczej (RWPG) oraz Układu Warszawskiego ${ }^{27}$. ZSRR intensywnie eksploatował Bułgarię, importując stamtąd bardzo dużo towarów i całkowicie uzależniając ją od radzieckich surowców energetycznych, przy czym import z państw RWPG do Bułgarii był znikomy.

Upadek komunizmu zmienił położenie polityczne Sofii, ale nie rozwiązał problemu zależności energetycznej. Jak już wspomniano, brak rodzimych zasobów surowcowych i dywersyfikacji źródeł energii ${ }^{28}$ jest istotnym czynnikiem pozwalającym Moskwie łatwo wpływać na politykę Bułgarii. Raz jeszcze podkreślmy, że zarówno ropę naftową, jak i gaz ziemny państwo to sprowadza wyłącznie z Rosji - poprzez ropociąg Przyjaźń i gazociąg Braterstwo biegnące przez Ukrainę i Rumunię.

W październiku 2016 r. amerykański ośrodek badawczy Centrum Studiów Strategicznych i Międzynarodowych (CSIS) opublikował w porozumieniu z bułgarskim Centrum Badań nad Demokracją (CSD) raport dotyczący wpływów Rosji w pięciu krajach Europy Środkowo-Wschodniej: Bułgarii, Łotwie, Serbii, Słowacji oraz na Węgrzech ${ }^{29}$. Wynika z niego, że Moskwa systematycznie wzmacnia w nich swoją pozycję, przede wszystkim w sferach politycznej i ekonomicznej. Powołując się na artykuły prasowe i dane statystyczne (np. Freedom House, Eurostatu i kalkulacje CSD), autorzy stwierdzają, że celem Rosji jest odwrócenie proeuropejskiego kierunku polityki tych państw i doprowadzenie do sytuacji, w której mogłaby realizować na ich terenie własne cele polityczne. Czytamy tam również, że dla wielu Bułgarów „prezentowanie postawy zarówno proeuropejskiej, jak i prorosyjskiej nie wyklucza się, a wręcz przeciwnie rozumiane jest w narodzie jako konieczność i manifestowane w polityce krajowej" ${ }^{30}$. Rosyjski udział w gospodarce Bułgarii jest tak silny, że państwu grozi polityczne i ekonomiczne przejęcie przez Rosję - w latach 2005-2014 wynosił średnio równowartość 22 proc. bułgarskiego $\mathrm{PKB}^{31}$. W celu zdobycia wpływu na rząd w Sofii Kreml zacieśnia współpracę z prorosyjskimi politykami z partii nacjonalistycznych i skrajnie prawicowych. W czerwcu 2016 r. liderzy BPS

27 B. Jelavich, Historia Bałkanów, t. 2: Wiek XX, Wydawnictwo Uniwersytetu Jagiellońskiego, Kraków 2005, s. 349-418.

28 W. Hebda, Strategia energetyczna Republiki Bułgarii do 2020 roku, „Polityka Energetyczna" 2015, t. 18, z. 2.

29 A.H. Conley, J. Mina, R. Stefanov, M. Vladimirov, The kremlin playbook. Understanding Russian influence in Central and Eastern Europe, Center for Strategic \& International Studies, październik 2016, dostępny w internecie [dostęp: 6 XI 2018]: <http://www. csd.bg/fileadmin/user_upload/160928_Conley_KremlinPlaybook_Web.pdf>.

30 Tamże, s. 43.

31 Dane zebrane na podstawie szacunków CSD opartych o dane Eurostatu, Freedom House, Narodowego Banku Centralnego, rejestry korporacyjne i bazy danych. Tamże, s. 42. 
i Alternatywy na rzecz Odrodzenia Bułgarii (ABW) uczestniczyli w kongresie Jednej Rosjii ${ }^{32}$, a dwa lata wcześniej przewodniczący partii Ataka Wolen Siderow kampanię wyborczą do Parlamentu Europejskiego rozpoczął w Moskwie, oskarżając Stany Zjednoczone o podżeganie do wybuchu trzeciej wojny światowej i przypominając Bułgarom, że „Matka Rosja nas oswobodziła”33.

Autorzy raportu zwracają uwagę, że Rosjanie posiadają duże udziały w takich sektorach bułgarskiej gospodarki jak: finanse, telekomunikacja, rynek nieruchomości i media. Polityka Kremla zmierza też do pogłębienia w Bułgarii patologii społecznych, np. korupcji. W celu utrzymania dominacji gospodarczej w tym kraju oraz ukrycia nielegalnych praktyk Rosjanie posuwają się do działań propagandowych, dezinformacji i łapówkarstwa. Stworzyli tam nietransparentną sieć - błędne koło klientów politycznych i ekonomicznych, poprzez które Moskwa kontroluje kluczowe instytucje oraz wywiera wpływ na zapadające w Sofii decyzje polityczne i ekonomiczne. Przykładem jest działalność Delana Peewskiego, potentata medialnego i przedsiębiorcy posiadającego ogromne udziały w bułgarskim rynku medialnym, energetycznym, telekomunikacyjnym i obronnym ${ }^{34}$.

Bezpieczeństwu Bułgarii zagrażają także inne problemy gospodarcze ${ }^{35}$. Jest to państwo o słabo rozwiniętym przemyśle i rolnictwie; nie należy ani do strefy euro, ani do obszaru Schengen. Wśród najważniejszych kwestii, z którymi musi się mierzyć, wymienia się słabość sektora finansowego, niskie PKB i poziom jego wzrostu, wysoki dług publiczny oraz duże bezrobocie i niskie wynagrodzenia, a co za tym idzie - wysoki poziom ubóstwa ${ }^{36}$. Wszystkie te problemy gospodarcze przekładają się na niestabilną sytuację polityczną i wzrost niezadowolenia społecznego.

32 Bulgaria's rivaling socialist parties to attend United Russia congress, „Novinite” [online], 25 VI 2016 [dostęp: 31 X 2018], dostępny w internecie: <https://www.novinite.com/articles/ $175125 /$ Bulgaria $\% 27 \mathrm{~s}+$ Rivaling + Socialist + Parties + to + Attend + United + Russia + Congress $>$.

33 G. Witte, Putin could be a winner in European parliamentary vote if far right gains ground, „Washington Post” [online], 19 V 2014 [dostęp: 31 X 2018], dostępny w internecie: <https:// www.washingtonpost.com/world/putin-could-be-a-winner-in-european-parliamentary-vote-if-far-right-gains-ground/2014/05/18/4de276e9-9ee3-4366-9102-81e91e03f182 story.html?utm_term $=.9 \mathrm{db} 29601 \mathrm{dca}>$.

34 A.H. Conley, J. Mina, R. Stefanov, M. Vladimirov, The kremlin playbook..., s. 1-4, 17-21.

35 B. Jóźwik, T. Stępniewski, Transformacja, integracja i kryzysy w Europie Środkowej i Wschodniej, „Rocznik Instytutu Europy Środkowo-Wschodniej” 2016, R. 14, z. 5. Szerzej na temat kondycji gospodarczej państw Europy Środkowo-Wschodniej zob. M. Grela, M. Humanicki, M. Kitala, T. Michałek, W. Mroczek, Sytuacja gospodarcza w krajach Europy Środkowej i Wschodniej, Instytut Ekonomiczny NBP, Warszawa 2015 (Sytuacja Gospodarcza w Krajach Europy Środkowej i Wschodniej, 1/15).

36 R. Woźnica, Butgarska polityka... 


\section{Zagrożenia społeczne}

Najważniejszym społecznym problemem Bułgarii wydaje się obecnie demografia, zwłaszcza depopulacja i emigracja zarobkowa ${ }^{37}$. Podczas gdy w połowie lat osiemdziesiątych kraj ten liczył 9 mln mieszkańców, to na początku 2017 r. już tylko 7,1 mln. Wiele badań stawia go wśród najszybciej kurczących się członków $U^{38}$. Według szacunków Krajowego Instytutu Statystycznego Bułgarii do 2030 r. nastąpi dalszy spadek ludności o 7 proc.; Komisja Europejska przewiduje natomiast, że do 2060 r. populacja tego państwa skurczy się aż o 25 proc. ${ }^{39}$ Jeśli prognozy się sprawdzą, to między 2013 a 2060 r. ubędzie ok. 40 proc. Bułgarów w wieku produkcyjnym. Raport Bułgarskiej Akademii Nauk oraz Fundacji im. Friedricha Eberta wskazuje z kolei, że Bułgaria jest państwem o największej umieralności w Europie, a istotną przyczyną spadku liczby ludności kraju jest emigracja ${ }^{40}$. Według szacunków w ciągu ostatnich trzydziestu lat za granicę wyjechało stamtąd 1,5-2 mln osób i co roku emigruje ok. 30 tys. kolejnych. Szczególnie problematyczna jest dla państwa coraz częstsza gotowość do wyjazdu ludzi starszych, powyżej pięćdziesiątego roku życia, co thumaczy się przede wszystkim niskimi zarobkami, fatalnym systemem ochrony zdrowia, brakiem perspektyw i korupcją. Niepokojącą tendencją jest też koncentracja ludności w kilku największych miastach kraju. Raport wskazuje, że w 2030 r. będzie je zamieszkiwać 42 proc. populacji, co spowoduje wyludnienie mniejszych miejscowości i wsi. Jedyną grupą, której nie dotyczy kryzys demograficzny, jest mniejszość romska. Prognozuje się,

37 Na temat depopulacji w bułgarskich wioskach zob. Ch. Mladenov, M. Ilieva, The depopulation of the Bulgarian villages, „Bulletin of Geography. Socio-Economic Series” 2012, No. 17, s. 99-107. O problemach demograficznych Bułgarii zob. Aktualiziranta nacionalna strategiâ za demografsko razvitie na naselenieto v Republika B"lgariâ (2012-2030 2.), „Ministerski s"vet” [online, dostęp: 22 X 2019], dostępny w internecie: $<$ http://www.strategy.bg/StrategicDocuments/View.aspx?lang=bg-BG\&Id=778>.

38 Y. Georgiev, Bulgaria's demographic challenge, „Emerging Europe” [online], 22 II 2018 [dostęp: 2 XI 2018], dostępny w internecie: <https://emerging-europe.com/voices/ bulgarias-demographic-challenge/>.

39 Tamże. Zob. też: The 2015 ageing report. Underlying assumptions and projection methodologies, European Commission, European Union 2014 (European Economy, 8), dostępny w internecie [dostęp: 2 XI 2018]: <http://ec.europa.eu/economy_finance/publications/ european_economy/2014/pdf/ee8_en.pdf $>$.

40 Butgaria ñ skraju przepaści. Wstrzasajacy raport o wyludnieniu, „TVN 24”, 19 X 2018 [dostęp: 2 XI 2018], dostępny w internecie: <https://www.tvn24.pl/wiadomosci-ze-swiata,2/wstrzasajacy-raport-o-bulgarii-naukowcy-przewiduja-wyludnienie,877324.html>. Zob. też raport Fundacji Friedricha Eberta z 2017 r.: I. Čipin, N. Ilieva, Coping with demographic decline in Croatia and Bulgaria, Friedrich Ebert Stiftung, [Zagreb] 2017, dostępny w internecie [dostęp: 2 XI 2018]: <http://library.fes.de/pdf-files/bueros/kroatien/13814.pdf $>$. 
że do 2030 r. jej liczba wzrośnie do 850 tys., a w 2050 - do 1,3 mln, czyli ok. 23 proc. ludności Bułgarii.

Problemy demograficzne w Bułgarii mają zupełnie inny charakter niż w państwach Europy Zachodniej, gdzie głównym wyzwaniem jest starzenie się społeczeństw, wynikające ze wzrostu średniej długości życia będącego efektem lepszej opieki medycznej i zdrowego trybu życia. Co prawda obserwuje się w Bułgarii ogólnoeuropejski trend do zmiany modelu rodziny i życia, np. emancypację kobiet czy ich mniejszą dzietność, ale skala tego zjawiska jest jeszcze stosunkowo niewielka. Podstawową przyczyną kryzysu demograficznego wydaje się zatem zła kondycja gospodarcza i społeczna państwa, które od początku transformacji ustrojowej ma problemy ze skutecznym wprowadzaniem koniecznych reform wewnętrznych ${ }^{41}$. Częste zmiany rządów, problemy gospodarcze i korupcja hamowały rozwój kraju i doprowadziły do głębokiego kryzysu gospodarczego w latach 1995-1997. Zmiana ustroju przyniosła ze sobą przemodelowanie struktury społecznej-wykształcenie się głębokiego podziału na ludzi bardzo biednych i bardzo bogatych. Niesprawne rządy i nieskuteczna walka z takimi patologiami społecznymi jak korupcja czy przestępczość odbijają się na kondycji bułgarskiego społeczeństwa i gospodarki, która nie ma warunków do efektywnego rozwoju. Istotnymi problemami Bułgarii są też zagrożenie ubóstwem i wykluczenie społeczne, według raportu Eurostatu najwyższe wśród wszystkich państw członkowskich UE ${ }^{42}$. Między 2008 a 2016 r. ryzyko to zmalało co prawda z 44,8 do 40,4 proc., ale Bułgaria wciąż zajmuje pod tym względem pierwsze miejsce. Przyczyną depopulacji kraju i emigracji są także niskie zarobki ${ }^{43}$. Z danych Eurostatu wynika, że wynosząca równowartość 235 euro bułgarska miesięczna płaca minimalna jest najniższa w całej UE. Niekorzystnie przedstawia się również sytuacja osób starszych, przechodzących

41 Szerzej na ten temat zob. R. Woźnica, Butgarska polityka... Zob. też: I. Angelov, Bulgarian strenghts and weaknesses on the verge of the EU accession, „Economic Annals” (Belgrad) 2007, vol. 52, No. 174-175, dostępny w internecie [dostęp: 2 XI 2018]: <http:// www.ekof.bg.ac.rs/wp-content/uploads/2014/06/174-5.pdf>; Democratic backsliding in Bulgaria, Institute for Market Economics, [b.d.m.w.], dostępny w internecie [dostęp: 2 XI 2018]: <https://ime.bg/var/images/IME_democractic_backsliding_English.pdf $>$.

42 Downward trend in the share of persons at risk of poverty or social exclusion in the EU, Eurostat, 16 X 2017 (Eurostat News Release, 155/2017), dostępny w internecie [dostęp: 3 XI 2018]: <http://ec.europa.eu/eurostat/documents/2995521/8314163/3-16102017-BP-EN.pdf/d31 fadc6-a284-47f3-ae1c-8212a581b0c1>.

43 National minimum wages in the EU monthly minimum wages below $€ 500$ in east and well above $€ 1000$ in northwest, Eurostat, 10 II 2017 (Eurostat News Release, 25/2017), dostępny w internecie [dostęp: 3 XI 2018]: <http://ec.europa.eu/eurostat/en/web/ products-press-releases/-/3-10022017-AP $>$. 
na emeryturę. Niski poziom tych świadczeń (w styczniu 2018 r. minimalna emerytura wynosiła równowartość ok. 100 euro) zmusza je do kontynuowania pracy w szarej strefie ${ }^{44}$. Wobec tak słabej kondycji państwa i niskiego poziomu życia wielu Bułgarów nie decyduje się na założenie rodziny lub jej powiększenie, ale rozważa poszukiwanie lepszego życia na długotrwałej emigracji. Exodus obywateli, a w konsekwencji brak wykwalifikowanej siły roboczej, negatywnie odbija się na bułgarskiej gospodarce i rynku pracy.

Bardzo poważnymi problemami społecznymi, którym musi sprostać państwo, są korupcja i przestępczość zorganizowana. Choć Bułgaria boryka się z tymi patologiami od początku przemian politycznych i niejednokrotnie już przeżywała z ich powodu kryzysy gospodarcze i polityczne (miała np. problemy z przystąpieniem do UE), to $\mathrm{w}$ ostatnich latach problemy poważnie przybierają na sile. Realizacja rządowych projektów walki z korupcją i przestępczością najczęściej kończy się niepowodzeniem. Raport CSD z 2014 r. informował, że poziom korupcji w Bułgarii był wówczas najwyższy od piętnastu la ${ }^{45}$. Niepokojący jest także fakt społecznego przyzwolenia na tego typu patologie, idący zresztą w parze z powszechną niechęcią i brakiem zaufania do instytucji publicznych. Wynika to z niezadowolenia obywateli z prowadzonej polityki, awersji wobec rządzących i ogólnego zniechęcenia życiem w ubóstwie.

\section{Podsumowanie}

Przytoczone wyżej argumenty pozwalają potwierdzić tezę, że współczesna Bułgaria narażona jest na wiele zagrożeń, w większości o charakterze wewnętrznym, co świadczy o jej kondycji i poziomie rozwoju społeczno-gospodarczego. Największą barierą dla wprowadzania realnych zmian wydaje się brak sterowności państwa, tzn. sprawnych mechanizmów kontroli i nadzoru oraz instytucji, które potrafią odpowiadać na potrzeby obywateli i dbać o ich interesy, bezpieczeństwo oraz rozwój. Państwo sterowne ma wysokie poczucie racji stanu, zabiega o swoje interesy (głównie wielopłaszczyznowe bezpieczeństwo), potrafi właściwie diagnozować zagrożenia i wyzwania, a następnie skutecznie na nie reagować. W przypadku Bułgarii na drodze stają liczne niekorzystne uwarunkowania wewnętrzne: częste zmiany rządów, obecność postkomunistów w parlamencie, korupcja

44 Y. Georgiev, Bulgaria's demographic challenge...

45 Antikorupcionni politiki sreŝu zavladâvaneto na d"ržavata, Cent"r za izsledvane na demokraciâta, Sofiâ 2014, dostępny w internecie [dostęp: 5 XI 2018]: <http://www.csd.bg/ artShowbg.php?id=17171>. 
na wszystkich szczeblach władzy i uzależnienie bułgarskiej energetyki od rosyjskich surowców, a także zagrożenie ingerencją Rosji w sprawy państwa. Wszystkie te problemy obniżają wiarygodność Bułgarii jako państwa demokratycznego i negatywnie wpływają na postrzeganie jej na arenie międzynarodowej. Sposobem na ograniczenie tych zagrożeń (w tym potencjalnej ingerencji Rosji) jest większa demokratyzacja oraz silniejsza integracja z UE, zwłaszcza na płaszczyźnie politycznej i gospodarczej, co mogłaby ułatwić ściślejsza integracja regionalna, np. w ramach Trójmorza.

\section{Bibliografia}

The 2015 ageing report. Underlying assumptions and projection methodologies, European Commission, European Union 2014 (European Economy, 8), dostępny w internecie [dostęp: 2 XI 2018]: <http://ec.europa.eu/economy_finance/publications/european_economy/2014/ pdf/ee8_en.pdf>.

Aktualiziranta nacionalna strategiâ za demografsko razvitie na naselenieto $v$ Republika B"lgariâ (2012-2030 2.), ,Ministerski s"vet” [online, dostęp: 22 X 2019], dostępny w internecie: $<$ http://www.strategy.bg/StrategicDocuments/View.aspx?lang=bg-BG\&Id=778>.

Ambareva H., Protests, politics and values in Bulgaria 2013, [w:] Social movements in Central and Eastern Europe. A renewal of protests and democracy, ed. G. Pleyers, I.N. Sava, Universității din București, București 2015.

Angelov I., Bulgarian strenghts and weaknesses on the verge of the EU accession, „Economic Annals" (Belgrad) 2007, vol. 52, No. 174-175, dostępny w internecie [dostęp: 2 XI 2018]: $<$ http://www.ekof.bg.ac.rs/wp-content/uploads/2014/06/174-5.pdf >

Antikorupcionni politiki sreŝu zavladâvaneto na d"ržavata, Cent"r za izsledvane na demokraciâta, Sofiâ 2014, dostępny w internecie [dostęp: 5 XI 2018]: <http://www.csd.bg/artShowbg.php?id=17171>.

Bujwid-Kurek E., Mikucka-Wójtowicz D., Transformacja ustroju politycznego wybranych państw Europy Środkowej i Poludniowo-Wschodniej, Wydawnictwo „Libron”, Kraków 2015.

Bulgaria in transition. Politics, economics, society and culture after communism, ed. J.D. Bell, Westview Press, Colorado 1998.

Bulgaria's rivaling socialist parties to attend United Russia congress, „Novinite” [online], $25 \mathrm{VI}$ 2016 [dostęp:31 X2018], dostępny w internecie: $<$ https://www.novinite.com/articles/175125/ Bulgaria $\% 27 \mathrm{~s}+$ Rivaling + Socialist + Parties + to + Attend+United + Russia + Congress $>$.

Bułgaria na skraju przepaści. Wstrzasający raport o wyludnieniu, „TVN 24”, 19 X 2018 [dostęp: 2 XI 2018], dostępny w internecie: <https://www.tvn24.pl/wiadomosci-ze-swiata,2/ wstrzasajacy-raport-o-bulgarii-naukowcy-przewiduja-wyludnienie,877324.html>.

Cartner H., Decommunization in Bulgaria, Human Rights Watch, Helsinki 1993 (The News from Helsinki Watch, 5, 14), dostępny w internecie [dostęp: 30 X 2018]: <https://www. hrw.org/sites/default/files/reports/BULGARIA938.PDF>.

Christova Ch., Foerger D., Lustration - addressing the consequences of the communist regime in Bulgaria, „International Reports” 2008, issue 1, dostępny w internecie [dostęp: 30 X 2018]: <https://www.kas.de/c/document_library/get_file?uuid=c4ffe7a7-4acb-e85b-a22a-0a6be7f95930\&groupId=252038>. 
Čipin I., Ilieva N., Coping with demographic decline in Croatia and Bulgaria, Friedrich Ebert Stiftung, [Zagreb] 2017, dostępny w internecie [dostęp: 2 XI 2018]: <http://library.fes.de/ pdf-files/bueros/kroatien/13814.pdf>.

Conley A.H., Mina J., Stefanov R., Vladimirov M., The kremlin playbook. Understanding Russian influence in Central and Eastern Europe, Center for Strategic \& International Studies, październik 2016, dostępny w internecie [dostęp: 6 XI 2018]: <http://www.csd. bg/fileadmin/user_upload/160928_Conley_KremlinPlaybook_Web.pdf $>$.

Crampton J.R., Bulgaria, Oxford University Press, Oxford 2008.

Democratic backsliding in Bulgaria, Institute for Market Economics, [b.d.m.w.], dostępny w internecie [dostęp: 2 XI 2018]: <https://ime.bg/var/images/IME_democractic_backsliding_English.pdf $>$.

Downward trend in the share of persons at risk of poverty or social exclusion in the EU, Eurostat, 16 X 2017 (Eurostat News Release, 155/2017), dostępny w internecie [dostęp: 3 XI 2018]: <http://ec.europa.eu/eurostat/documents/2995521/8314163/3-16102017-BP-EN.pdf/d31 fadc6-a284-47f3-ae1c-8212a581b0c1>.

Dymarski M., Konflikty na Bałkanach w okresie ksztaltowania się państw narodowych w XIX i na początku XX wieku, Wydawnictwo Uniwersytetu Wrocławskiego, Wrocław 2010.

Eberhardt P., Rosyjski panslawizm jako idea geopolityczna, „Geopolityka” [online], $19 \mathrm{~V}$ 2012 [dostęp: 1 XI 2018], dostępny w internecie: <http:/geopolityka.net/rosyjski-panslawizm-jako-idea-geopolityczna/>.

„Europa Środkowo-Wschodnia” (ISP PAN).

Fala protestów obalita butgarski rząd, „W Polityce” [online], 22 II 2013 [dostęp: 28 X 2018], dostępny w internecie: $<$ https://wpolityce.pl/polityka/151584-fala-protestow-obalila-bulgarski-rzad $>$.

Ganev V.I., Bulgaria's year of civic anger, „Journal of Democracy” 2014, vol. 25, No. 1, dostępny w internecie [dostęp: 30 X 2018]: <https://www.journalofdemocracy.org/article/ legacies-1989-bulgarias-year-civic-anger $>$.

Georgiev Y., Bulgaria's demographic challenge, „Emerging Europe” [online], 22 II 2018 [dostęp: 2 XI 2018], dostępny w internecie: <https://emerging-europe.com/voices/ bulgarias-demographic-challenge/>.

„GERB” [online, dostęp: 8 VIII 2019], dostępna w interrnecie: <http://www.gerb.bg/bg>.

Grela M., Humanicki M., Kitala M., Michałek T., Mroczek W., Sytuacja gospodarcza w krajach Europy Środkowej i Wschodniej, Instytut Ekonomiczny NBP, Warszawa 2015 (Sytuacja Gospodarcza w Krajach Europy Środkowej i Wschodniej, 1/15).

Hallberg D., Ossewaarde M., Protest and recognition in the Bulgarian summer 2013 movement, [w:] Protest, social movements and global democracy since 2011. New perspectives research in social movements, conflicts and change, ed. T. Davies, H. E. Ryan, A. Milciades Pena, Emerald Group Publishing Limited, Bingley 2016 (Research in Social Movements, Conflicts and Change, 39).

Hebda W., Strategia energetyczna Republiki Butgarii do 2020 roku, „Polityka Energetyczna” 2015, t. 18, z. 2.

Holzer J., Komunizm w Europie. Dzieje ruchu i systemu władzy, Dom Wydawniczy „Bellona”, Warszawa 2000.

Hristov H., Komisiâta „Bonev” i neefektivnostta na p"rviâ zakon za dosietata, „D"ržavna sigurnost” [online], 13 X 2011 [dostęp: 22 X 2019], dostępny w internecie: $<$ https://desebg. com/komisii/436-2011-10-13-19-24-10>. 
Hristov H., Propusnatite istoričeski momenti za lustraciâ v B"lgariâ, „D"ržavna sigurnost” [online], 1 II 2011 [dostęp: 22 X 2019], dostępny w internecie: <https://desebg.com/ lustracia/79-2011-02-01-00-13-56>.

Ideology and social movements. A comparative analysis of the 2013 protests in Bulgaria, Hungary and Romania, [w:] Social movements in Central and Eastern Europe. A renewal of protests and democracy, ed. G. Pleyers, I.N. Sava, Universității din București, București 2015.

Jelavich B., Historia Bałkanów, t. 2: Wiek XX, Wydawnictwo Uniwersytetu Jagiellońskiego, Kraków 2005.

Jóźwik B., Stępniewski T., Transformacja, integracja $i$ kryzysy w Europie Środkowej i Wschodniej, „Rocznik Instytutu Europy Środkowo-Wschodniej” 2016, R. 14, z. 5.

Kalinova E., Baeva I., B"lgarskite prehodi 1939-2010, Izdatelstvo „Paradigma”, Sofiâ 2010.

Karasimeonov G., Partijnata sistema v B"lgariâ, Izdatelstvo „Nik”, Sofiâ 2010.

Kłaczyński R., Polityka Imperium Rosyjskiego wobec państw, narodów bałkańskich 1826-1914, „Studia Środkoweuropejskie i Bałkanistyczne” 2017, t. 26.

Komisiâ, „Regist"r na s"trudnicite na d"ržavna sigurnost i razuznavatelnite službi na BNA” [online, dostęp: 23 X 2019], dostępny w internecie: <https://agentibg.com/index.php/ bg/2014-02-19-06-31-22/2014-02-19-06-33-02>.

Krastev I., Why Bulgaria's protest stand out in Europe, „The Guardian” [online], 30 VII 2013 [dostęp: 30 X 2018], dostępny w internecie: <https://www.theguardian.com/ commentisfree/2013/jul/30/bulgaria-protests-europe $>$.

Lustracja w krajach Europy Środkowej i państw battyckich, red. P. Bukalska i in., Ośrodek Studiów Wschodnich, Warszawa 2009.

Mladenov Ch., Ilieva M., The depopulation of the Bulgarian villages, „Bulletin of Geography. Socio-Economic Series" 2012, No. 17.

National minimum wages in the EU monthly minimum wages below 6500 in east and well above $€ 1000$ in northwest, Eurostat, 10 II 2017 (Eurostat News Release, 25/2017), dostępny w internecie [dostęp: 3 XI 2018]: <http://ec.europa.eu/eurostat/en/web/products-press-releases/-/3-10022017-AP>.

Nowakowski M., Bułgaria, [w:] Lustracja w krajach Europy Środkowej i państw battyckich, red. P. Bukalska i in., Ośrodek Studiów Wschodnich, Warszawa 2009.

Parlament przyjąt dymisję rządu Bojko Borisowa, „Newsweek” [online], 21 II 2013 [dostęp: 28 X 2018], dostępny w internecie: $<$ http://www.newsweek.pl/swiat/bulgaria--parlamentprzyjal-dymisje-rzadu-bojko-borysowa,101715,1,1.html $>$.

Partie i systemy partyjne państw Europy Środkowej i Wschodniej, red. M. Migalski, Wyższa Szkoła Zarządzania i Marketingu, Sosnowiec 2005.

Pioskowik E., Bułgaria, [w:] Partie i systemy partyjne państw Europy Środkowej $i$ Wschodniej, red. M. Migalski, Wyższa Szkoła Zarządzania i Marketingu, Sosnowiec 2005.

Prehod"t: mitove i pamet. 25 godini po-k"sno, Alpha Research, 9 XI 2014, dostępny w internecie [dostęp: 30 X 2018]: <https://alpharesearch.bg/userfiles/file/Prehod_press_release_091114.pdf>.

Protest, social movements and global democracy since 2011. New perspectives research in social movements, conflicts and change, ed. T. Davies, H.E. Ryan, A. Milciades Pena, Emerald Group Publishing Limited, Bingley 2016 (Research in Social Movements, Conflicts and Change, 39).

Radew zaprzysiężony na prezydenta, „TVN 24” [online], 19 I 2017 [dostęp: 10 X 2017], dostępny w internecie: <https://www.tvn24.pl/wiadomosci-ze-swiata,2/bulgaria-rumen-radew-prezydentem, 708401.html>. 
Rezultati ot izbori za narodni predstaviteli 12.05.2013 g., „Centralna izbiratelna komisiâ” [online, dostęp: 1 IX 2019], dostępne w internecie: <http://results.cik.bg/pi2013/rezultati/index.html >.

Rezultati ot parlamentarni izbori 26 mart 2017. Sumarni danni, „Centralna izbiratelna komisiâ" [online, dostęp: 10 X 2017], dostępne w internecie: <https://web.archive.org/ web/20170331173208/http://results.cik.bg/pi2017/rezultati/index.html>.

Rocznik Instytutu Europy Środkowo-Wschodniej, „Instytut Europy Środkowo-Wschodniej” [online, dostęp: 1 IX 2019], dostępny w internecie: <http://www.iesw.lublin.pl/rocznik/spisroczniki.php>.

Sobczak J., Kwestia bałkańska w rosyjskiej polityce zagranicznej z przełomu XIX i XX wieku i jej polskie epizody, „Acta Polono-Ruthenica” 2003, nr 8.

Social movements in Central and Eastern Europe. A renewal of protests and democracy, ed. G. Pleyers, I.N. Sava, Universității din București, București 2015.

Tanty M., Bałkany w XX wieku. Dzieje polityczne, Wydawnictwo „Książka i Wiedza”, Warszawa 2003.

Tanty M., Konflikty batkańskie w latach 1878-1918, Państwowe Zakłady Wydawnictw Szkolnych, Warszawa 1968.

Wasilewski T., Historia Bułgarii, Zakład Narodowy im. Ossolińskich, Wrocław 1988.

Witte G., Putin could be a winner in European parliamentary vote if far right gains ground, „Washington Post” [online], 19 V 2014 [dostęp: 31 X 2018], dostępny w internecie: <https:// www.washingtonpost.com/world/putin-could-be-a-winner-in-european-parliamentaryvote-if-far-right-gains-ground/2014/05/18/4de276e9-9ee3-4366-9102-81e91e03f182_ story.html?utm_term=.9db29601dca3>.

Wojnicki J., Alternacja władzy w państwach Europy Środkowo-Wschodniej po 1990 roku, „Studia Politicae Universitatis Silesiensis” 2011, t. 7.

Wojnicki J., Trudna droga do demokracji. Europa Środkowo-Wschodnia po 1989 roku, Wydawnictwo Autorskie, Warszawa 2002.

Woźnica R., Bułgarska polityka wewnętrzna a proces integracji z Unia Europejska, Księgarnia Akademicka, Kraków 2011.

Zakon za dost"p do dokumentite na bivšata D"ržavna sigurnost, 6 VIII 1997, dostępny w internecie [dostęp: 22 X 2019]: <https://desebg.com/images/stories/videos/Pdf/Zakon-zadosietata-1997.pdf>.

Zakon za dost"p i razkrivane na dokumentite i za obâvâvane na prinadležnost na b"lgarski graždani k"m d"ržavna sigurnost i razuznavatelnite službi na B"lgarskata narodna armiâ, „B"lgarskiât praven portal” [online, dostęp: 30 X 2018], dostępny w internecie: <https:// www.lex.bg/laws/ldoc/2135540283>.

Zakon za vremenno v"veždane na nâkoi dop"lnitelni iziskvaniâ $k^{\prime \prime} m$ členovete na $r$ "kovodstvata na naučnite organizacii i Visšata atestacionna komisiâ, 24 XII 1992, dostępny w internecie [dostęp: 21 X 2019]: <https://desebg.com/images/stories/videos/Pdf/Zakon_Panev.pdf>.

Zakon za zasita na klasificiranata informaciâ, 30 IV 2002, „B"lgarskiât praven portal” [online, dostęp: 22 X 2019], dostępny w internecie: <https://www.lex.bg/laws/ldoc/2135448577>. 